\title{
The Analysis of Teacher's Needs Toward Science Learning for Elementary Students with Mild Mental Retardation
}

\author{
Tri Wiryanto; Sunardi; Joko Yuwono \\ Postgraduate of Special Education, Sebelas Maret University, Indonesia \\ http://dx.doi.org/10.18415/ijmmu.v8i9.2924
}

\begin{abstract}
Learning media is one of the important things in the child's learning process. The purpose of this study is to determine the teacher's needs of learning media for children with special needs with mild mental retardation in science learning. This research technique uses a qualitative descriptive research method by conducting a needs analysis. The research subject is a teacher at a special school who teaches mild mental retardation. The results showed that the used learning media were not varied. Based on the explanation above, the development of media really needs to be conducted by the teacher. The conclusion of this study found that the learning media used by teachers in science learning still needs to be developed.
\end{abstract}

Keywords: Science Learning; Learning Media; Mental Retardation

\section{Introduction}

Sciences is one of the fields of study taught in the education curriculum in Indonesia. The purpose of having science education in elementary schools should be to foster student curiosity scientifically (Astawan \& Agustiana, 2020). Science learning is expected to help students understand natural phenomena that occur. Based on its characteristics, science learning is divided into two sides as a product of the work of scientists and science learning as a process. In science learning, students are trained to be able to recognize facts, know the differences and similarities of facts, look for relationships between facts so that students can construct their own knowledge (Tala \& Vesterinen, 2015).

Science learning is not only for primary and secondary school curricula, but special schools also have a curriculum that includes science learning. Learning for children with special needs requires a separate pattern according to the needs of each student due to the different characteristics of each student with special needs (Suchyadi, Ambarsari, \& Sukmanasa, 2018). This requires teachers to be able to align the existence of their students with the existing curriculum. The curriculum for children with special needs is not only for children with physical disabilities but also intellectual. Intellectual barriers in children are also known as mental retardation. 
Students with mental retardation have the same rights in obtaining education. One of the classifications of mental retardation is also known as Educable Mentally Retardation which refers to how mentally retarded students as students in schools are able to be educated (Beirne-Smith, Patton, \& Kim, 2005). According to (Garnida, 2016) mild mentally retarded students have many advantages and abilities that can still be developed using different methods. Research conducted by (Özdemir \& Karaman, 2017) found that mild mentally retarded children do have characteristics that are difficult to learn, forget quickly, and have low memory skills. But by using slow or repeated speech methods and concrete examples in providing a lesson, mild mentally retarded children are able to be educated and are able to be trained (Wagino \& Rofiah, 2020)

The importance of fun and concrete learning makes teachers or instructors have to think creatively in providing learning media for mentally retarded students. Described by (Seechaliao, 2017) learning strategies that support the creation of creative and innovative education must focus on a systems approach, learning strategies which are usually based on design-based learning, problem solving, creative problem solving, creative thinking, research based learning, problem-based learning, project-based learning, science, or innovative teaching processes that can lead to creatively innovative education. There are many media that can be developed by teachers such as visual media but according to research conducted by (Alfin, Nadhiroh, Imani, \& Vadhilah, 2020) there are many challenges for teachers to develop this media. First, there are too many media that had been used. Second, it takes a long time to prepare the visual media and the last is from an economical point of view. The required materials to create visual media are expensive. In other words, the teacher must be more creative in developing the media so that it is appropriate for the target and does not cost a lot.

The implementation of learning is strongly influenced by the applied methods and learning media (Jalinus \& Ambiyar, 2016). One of the function of learning media in the implementation of student learning is that it can foster enthusiasm or encouragement for students' learning because teaching will attract their interest (Dhany Ersanty, 2020). The challenges and developments of the times as well as the development of technology make teachers able to innovate with technology. Teachers must be able to see the value of technology and be confident in using it for their students and feel the positive effects of technology integration (An \& A, 2021). The use of media in learning has undergone many changes starting from its initial physical form and nowadays there are many online learning media (Uzun, 2012). Even so, sometimes teachers do not really design learning with the right media (Grosch, Berger, Gidion, \& Romeo, 2014).

Mentally retarded students and learning media are inseparable things. The need for concrete and interesting media is something that the teacher must pay attention to. This is the background of the need for this research. The purpose of this study is to review the needs of learning media needed by special school teachers in providing science learning for students with mental retardation.

\section{Method}

\section{Type of Research}

This research is a qualitative descriptive study. In this study, an analysis of learning media needs was conducted. The analysis was conducted thoroughly regarding the needs of learning media needed by teachers of students with mild mental retardation in Surakarta.

\section{Time and Place of Research}

This research was conducted in June 2021. The place of research was conducted at the Special School (SLB) in Surakarta. Research subjects were selected using the purposive sampling method. Purposive sampling is a sampling technique for data sources with certain considerations (Sugiyono, 2015). The purposive sampling method was chosen because the subject is a teacher in an special school who teaches students with mild mental retardation. 


\section{Research Procedure}

The data were taken by using interview techniques and direct observation of the condition of the learning media used by the teacher. Interviews were conducted with teachers in special schools with mentally retarded students in the science subject learning. The next stage is to conduct an observation by directly observing the circumstances of the use of a medium of learning in school. In addition, observation function is to strengthen the analysis.

\section{Research Instrument}

The instrument was made by using 5 aspects consisting of (1) the types of learning media commonly used; (2) Frequency of digital media use; (3) The advantages of learning media that are commonly used; (4) Lack of learning media used and (5) Teacher's difficulties in developing learning media. The fifth aspect is used because it is considered as the main aspects that need to be observed in the use of learning media in science learning.

\section{Data Analysis Technique}

The data from the interviews were analyzed descriptively. The analysis is directed based on the needs of learning media needed by special school teachers with mild mentally retarded students in science learning materials. The result of data analysis is in the form of a descriptive description.

\section{Result and Discussion}

After the observations and interviews with teachers, the data obtained had been summarized as follows which are contained in table 1 .

\begin{tabular}{|l|l|l|}
\hline No & Aspect & Response \\
\hline 1 & Types of learning media commonly used & Whiteboards, textbooks, printed pictures, flashcards \\
\hline 2 & $\begin{array}{l}\text { Frequency of digital media use in } \\
\text { learning }\end{array}$ & $\begin{array}{l}\text { Once per chapter, but not regularly because the teacher } \\
\text { still doesn't understand how to use the right one for } \\
\text { mentally retarded children and the content displayed is } \\
\text { less diverse }\end{array}$ \\
\hline 3 & $\begin{array}{l}\text { The advantages of commonly used } \\
\text { learning media }\end{array}$ & $\begin{array}{l}\text { The use of blackboards and textbooks is very practical and } \\
\text { it does not require a lot of supporting facilities }\end{array}$ \\
\hline 4 & $\begin{array}{l}\text { Lack of commonly used learning media } \\
\text { Teacher constraints in developing }\end{array}$ & $\begin{array}{l}\text { Students feel bored with the use of textbooks and } \\
\text { blackboards because they are monotonous }\end{array}$ \\
\hline $\begin{array}{l}\text { Media development has not been developed because the } \\
\text { material taught is not only science but a lot and sometimes } \\
\text { mentally retarded children themselves are difficult to } \\
\text { catch what is being explained. } \\
\text { During the current pandemic, our learning is very } \\
\text { disrupted because we cannot meet face to face with } \\
\text { students. Hope there is a learning media that is suitable for } \\
\text { children when distance learning programs are like today }\end{array}$ \\
\hline
\end{tabular}

Table 1. Result of Observation and Interview

The data obtained after observations and interviews show the need for science learning media for mentally retarded students. The types of media used by teachers still tend to use physical media such as blackboards, printed books and very conventional printed pictures. It can be concluded that the use of technology in learning media is still minimal. There is a possibility that conventional learning is still used because teacher thinks that conventional learning is sufficient (van der Veen \& van Oers, 2017). Such a thought will be attached to teachers, especially special school teachers because of an understanding of the 
barriers in the intellectual context that occur in mild mentally retarded children (Avi Yanni, Kamala, Salih Assingkily, \& Rahmawati, 2020).

Learning science for mentally retarded children is very important because there are many ways to take care of themselves and so on in the learning. The principles of learning for mentally retarded students in general include the principle of compassion, the principle of individual service, the principle of readiness, the principle of demonstration, the principle of motivation, the principle of learning and working in groups, the principle of skill, and the principle of inculcating and perfecting attitudes. With this principle, the learning of students with mild mental retardation can be planned well until the implementation of learning (Dhany Ersanty, 2020).

Mentally retarded students will quickly get bored with conventional learning media. Therefore, media development must be adapted to the characteristics of the existing class (Wolfson \& Funke, 2014). Classes for children with mild mental retardation must provide interesting learning for children. This is in accordance with the results of research concerning the shortage of learning media that is the children are easily bored with the media provided by the teacher.

The need for the development of science learning media for mentally retarded students can take advantage of current developing technology in the form of internet and digital services. Research conducted by (de Wit, Dozeman, Ruwaard, Alblas, \& Riper, 2015) found that internet use in children with mild mental retardation had feelings of pleasure in the subject as evidenced by the subject who was able to operate how to contact the coach, which then concluded that the internet can improve children's daily independence functions and reduce their dependence on coaches. In addition, the use of the internet on social media makes mentally retarded children more able to express themselves, reduce stigma, and advocate for self-determination (Chadwick, Wesson, \& Fullwood, 2013). It can be concluded that technological developments can be used in the learning process of mentally retarded children on science material.

Many science learning materials take daily activities so that they can be synchronized between the use of technology and the development of science learning media for mentally retarded students. Image hyperlinks increase subject speed, subject attention and interest faster than text hyperlinks. Images can attract the attention of users and can improve their understanding proved by the amount of cartoons that get more views and clicks than the text (Rocha et al., 2012). During the current pandemic, teachers complain about activities that cannot be conducted face-to-face and suitable learning media for mentally retarded children. The process of teaching mentally retarded students at the discussion stage is hampered by the current pandemic (Sitti Nuralan, 2020). Online learning for children with special needs still requires a lot of media and evaluation of forms of online learning for students with special needs (Terayanti, 2020).

The analysis of teacher needs conducted by researchers found that in fact teachers' use of technology in learning process are still very low and there is a discrepancy in the content that exists in the learning media so that students have difficulty in understanding the presented material. In addition, the current pandemic situation which requires online learning adds note in making learning media that can cover all problems. Teachers as facilitators in the teaching and learning process must have an active role in designing the learning (Nesmith et al., 2016). Therefore, it is possible to develop learning media for science subjects for mentally retarded students because of the low content included in it. In addition, teachers have to conduct evaluations that involve students' participation (Ho, MacGlashan, Littman, \& Cushman, 2017).

\section{Conclusions and Suggestions}

\section{Conclusions}

The learning media used by teachers and students with mental retardation in science learning materials are still conventional and not diverse. Teachers still find it difficult to develop online media 
during this pandemic. There are many factors influence this such as teachers who do not have competence in developing materials, teachers who do not have much time to develop media, and learning media for mentally retarded children themselves which can be found minimally to help the learning process.

\section{Suggestions}

In the future, it is hoped that a program or technology will be developed in science learning materials so that in a pandemic or not, the media can be used in the learning process and be attractive to children with mild mental retardation.

\section{Bibliography}

Alfin, J., Nadhiroh, A. L., Imani, M. K., \& Vadhilah, U. (2020). The Challenges of Pre-Service Teacher in Creating Visual Instructional Media. 434(Iconelt 2019), 295-298. https://doi.org/10.2991/assehr.k.200427.059.

An, Y., \& A, Y. (2021). History of Instructional Instructional Design, and Theories Media, To cite this article : of A History of Instructional Media, Instructional Design, and Theories. 0-21.

Astawan, I. G., \& Agustiana, I. G. A. T. (2020). Elementary School Science Education in the IndustriaL Revolution Era 4.0. Bali: Nilacakra.

Avi Yanni, Kamala, I., Shaleh Assingkily, M., \& Rahmawati, R. (2020). The Analysis of Intellectual Ability of Children with Mild Mental Retardation at Demakijo 2 Elementary School. Education Journal, 21(1), 64-75. https://doi.org/10.33830/jp.v21i1.843.2020.

Beirne-Smith, M., Patton, J., \& Kim, S. (2005). Mental Retardation: An Introduction to Intellectual Disability (7th editio). Upper Saddle River, NJ: Pearson Education.

Chadwick, D., Wesson, C., \& Fullwood, C. (2013). Internet Access by People with Intellectual Disabilities: Inequalities and Opportunities. Future Internet, 5(3), 376-397. https://doi.org/10.3390/fi5030376.

de Wit, J., Dozeman, E., Ruwaard, J., Alblas, J., \& Riper, H. (2015). Web-based support for daily functioning of people with mild intellectual disabilities or chronic psychiatric disorders: A feasibility study in routine practice. Internet Interventions, 2(2), 161-168. https://doi.org/10.1016/j.invent.2015.02.007.

Dhany Ersanty. (2020). Web Based Learning for Students with Mild Mental Retardation. Special Education, 1-14.

Garnida, D. (2016). Module for Special School Teacher (Mental Retardation). Bandung: PPPPTK TK AND PLB BANDUNG.

Grosch, M., Berger, R., Gidion, G., \& Romeo, M. (2014). Which Media Services do Students Use in Fact? Results of an International Empirical Survey. Procedia - Social and Behavioral Sciences, 141, 795-806. https://doi.org/10.1016/j.sbspro.2014.05.139.

Ho, M. K., MacGlashan, J., Littman, M. L., \& Cushman, F. (2017). Social is special: A normative framework for teaching with and learning from evaluative feedback. Cognition, 167, 91-106. https://doi.org/10.1016/j.cognition.2017.03.006.

Jalinus, N., \& Ambiyar. (2016). Media \& Learning Source. Jakarta: Kencana.

Nesmith, S. M., Wynveen, C. J., Dixon, E. M., Brooks, B. W., Matson, C. W., Hockaday, W. C., ... 
DeFillipo, J. E. (2016). Exploring Educators' Environmental Education Attitudes and Efficacy: Insights Gleaned from a Texas Wetland Academy. International Journal of Science Education, Part B: Communication and Public Engagement, 6(3), 303-324. https://doi.org/10.1080/21548455.2015.1078519.

Özdemir, D., \& Karaman, S. (2017). Investigating interactions between students with mild mental retardation and humanoid robot in terms of feedback types. Egitim ve Bilim, 42(191), 109-138. https://doi.org/10.15390/EB.2017.6948.

Rocha, T., Bessa, M., Gonçalves, M., Cabral, L., Godinho, F., Peres, E., ... Chalmers, A. (2012). The Recognition of Web Pages' Hyperlinks by People with Intellectual Disabilities: An Evaluation Study. Journal of Applied Research in Intellectual Disabilities, 25(6), 542-552. https://doi.org/10.1111/j.1468-3148.2012.00700.x.

Seechaliao, T. (2017). Instructional Strategies to Support Creativity and Innovation in Education. Journal of Education and Learning, 6(4), 201. https://doi.org/10.5539/jel.v6n4p201.

Sitti Nuralan, S. T. D. (2020). The Analysis of Teacher's Teaching Process in Offline Learning during Covid - 19 Pandemic toward Students with Mental Retardation at Tolitoli Special School. Nusantara: Education Journal, 1(2), 47-57.

Suchyadi, Y., Ambarsari, Y., \& Sukmanasa, E. (2018). Analysis of Social Interaction of Mentally Retarded Children. Jhss (Journal of Humanities and Social Studies), 2(2), 17-21. https://doi.org/10.33751/jhss.v2i2.903.

Sugiyono. (2015). Educational Research Methode. Bandung: ALFABETA.

Tala, S., \& Vesterinen, V. M. (2015). Nature of Science Contextualized: Studying Nature of Science with Scientists. Science and Education, 24(4), 435-457. https://doi.org/10.1007/s11191-014-9738-2.

Terayanti, Y. A. (2020, December 22). The Impact of Learning toward Children with Special Needs during Covid 19 Pandemic. https://doi.org/10.17605/OSF.IO/TYQEH.

Uzun, N. (2012). A Sample of Active Learning Application in Science Education: The Thema "Cell" with Educational Games. Procedia - Social and Behavioral Sciences, 46, 2932-2936. https://doi.org/10.1016/j.sbspro.2012.05.592.

van der Veen, C., \& van Oers, B. (2017). Advances in research on classroom dialogue: learning outcomes and assessments. Learning and Instruction, 48, 1-4. https://doi.org/10.1016/j.learninstruc.2017.04.002.

Wagino, W., \& Rofiah, K. (2020). Freedom of Learning and Children with Mental Retardation at School. (Webinar) National Education Seminar 2020. Retrieved from https://fip.unesa.ac.id/fipppti/public/proceeding/index.php/webinar2020/article/view/127.

Wolfson, T., \& Funke, P. N. (2014). Communication, class and concentric media practices: Developing a contemporary rubric1. New Media and Society, 16(3), 363-380. https://doi.org/10.1177/1461444813481199.

\section{Copyrights}

Copyright for this article is retained by the author(s), with first publication rights granted to the journal.

This is an open-access article distributed under the terms and conditions of the Creative Commons Attribution license (http://creativecommons.org/licenses/by/4.0/). 